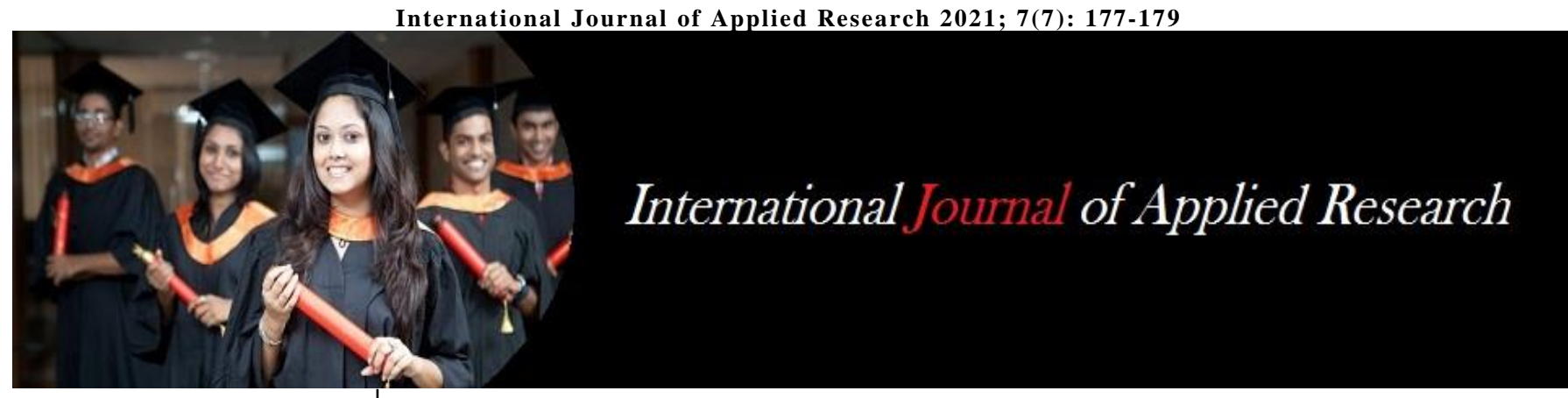

ISSN Print: 2394-7500

ISSN Online: 2394-5869

Impact Factor: 8.4

IJAR 2021; 7(7): 177-179

www.allresearchjournal.com

Received: 19-04-2021

Accepted: 21-05-2021

Ashish Kumar Das Mohapatra Faculty, Department of Int. B.Ed., MPC Autonomous College, Takhatpur, Baripada Odisha, India
Corresponding Author: Ashish Kumar Das Mohapatra Faculty, Department of Int. B.Ed., MPC Autonomous College, Takhatpur, Baripada, Odisha, India

\section{Impact of ICT on the academic achievement of secondary school students}

\author{
Ashish Kumar Das Mohapatra
}

\begin{abstract}
The purpose of the study is to explore the impact of ICT on the academic achievement of students at the secondary school level. Thirty students from a group of students studying in the secondary level participated in the study. By using a pre-test, treatment and post - test single group experimental research design data were collected about the ICT adoption in classroom and the relative academic performance of students. ICT teaching learning modules on physical science are developed for implementation of the intervention programme. The data analysed and interpreted by using the statistical techniques such as mean, SD \& t-ratio. The study found that there is significant effect of ICT on the academic achievement of the students. Finally, the study suggests that proper steps should be taken by the policy makers, administrators and academicians of different educational institutions to promote the use of ICT for focusing academic purposes.
\end{abstract}

Keywords: academic achievement, effectively, Information and Communication Technology

\section{Introduction}

Technology use is spreading rapidly into daily life, and directly affecting people's ideas and behaviour. ICT has an impact in many areas including the education system. ICT heralded the development and implementation of new and innovative teaching strategies in educational institution's educators who advocate technology integration in the learning process believe it will improve learning and prepare students to effectively participate in the $21^{\mathrm{ST}}$ century work place. ICT use has become a way of life for the majority of students all around the world. For most students the ICT is a functional tool, one that has greatly changed the way they interact with others and with information as they go about their studies. According to a study carried out by Eguavoen (2016) ${ }^{[3]}$ on the visual impairment students indicates that there was significant relationship between information and communication technology utilisation and academic performance of students with visual impairment. Another study done by Sharma (2015) examined the impact of teaching through different Information and Communication Technology (ICT) tools on the academic achievement of pupil teachers in Educational Technology. The findings of the study revealed that sample scored higher on post-test then pre-test after being taught through different ICT tools.

Globalization and innovations in technology have led to an increased use of ICTs in all sectors - and education is no exception. Uses of ICTs in education are widespread and are continually growing worldwide. It is generally believed that ICTs can empower teachers and learners, making significant contributions to learning and achievement. Of the teachers interviewed on the effectiveness of ICT in education majority of them felt that introduction and use of ICT adequately will be extremely effective in children's learning and achievement. In an investigation it found ICT has a positive effect on the achievement scores in mathematics test, but failed to increase achievement scores in language test also the introduction of ICT makes learning of physics so interesting for the students. [Carrillo, Onofa and Ponce (2010)] ${ }^{[2]}$. Safdar, Yousuf Parveen and Behlol, (2011) ${ }^{[5]}$ conducted an experimental study to identify the effectiveness of ICT in teaching mathematics at secondary level and they found that information and communication technology is very effective in teaching mathematics as compared to traditional teaching method.

Availability and usage of ICT improves the knowledge and learning skills of students and also the existence of ICT is improving the educational efficiency as well as obliging for 
making policies regarding education sector [Nisar Munir and Shad (2011)] ${ }^{[4]}$. Furthermore Ziden, Ismail, Spian, and Kumutha (2011) ${ }^{[7]}$ carried out an experimental study and concluded that ICT has a positive effect on the academic accomplishment of students in science subjects. This study additionally endeavoured to decide the distinctions of accomplishment between the female and male participants. The study found that male students showed better performance as compared to female students. A study yields few conclusive statements about the impacts of ICTs on secondary students' achievement. It discovered that the ICT program is more compelling and effective than the conventional teaching approach in terms of students' achievement scores in chemistry [Avinash and Shailja (2013) ${ }^{[1]}$.

\section{Objectives of the study}

The objectives of the study are

- To develop intervention program on ICT for teaching of physical science.

- To study the effectiveness of intervention program based on ICT to enhance the academic performance of secondary school students.

\section{Hypotheses of the study}

1. There exists a significant difference between pre- test and post- test score of achievement test.

2. There exists a significant difference between the posttest score of male and female secondary students on the achievement test.
3. There exists a significant difference between the posttest score of rural and urban secondary students on the achievement test.

\section{Methodology}

The study was based on an experimental research design. In this study the class IX students of a secondary school were taken as population. And from this above population 30 students from Class IX (each 15 from boys and girls) were selected as samples by the utilization of simple random sampling technique. A self-made standardized tool was used to find the effectiveness of ICT on the academic achievement of secondary students. The test has been divided into four areas comprising 40 items for assessing students' achievement. The various sections of the test comprise of multiple choice, fill in the blanks, one-word substitution and true \& false types of questions. All the questions are planned in order to check students' cognitive ability. The correlation coefficient of the tool is determined by using Karl Pearson's product moment method and the reliability coefficient is determined by using the Spearman Brown prophecy. The co-efficient of reliability is calculated and come out to be 0.74 . After conduction of pre-test on said samples, the researcher developed intervention program based on ICT teaching learning modules on with help of the concerned subject expert, language expert, ICT expert and an education resource person.

\section{Analysis and Interpretation}

Hypothesis-1: There exist a significant difference between pre-test and post-test score in the achievement test.

Table 1: Significance of difference between pre-test and post-test scores of students in the achievement test

\begin{tabular}{|c|c|c|c|c|c|c|}
\hline Test & N (No. of samples) & Mean & S. D. & S. Ed. & t-ratio & Level of significance \\
\cline { 1 - 4 } Pre-test & 30 & 25.36 & 4.49 & \multirow{2}{*}{1.16} & \multirow{2}{*}{4.17} & Significant difference at \\
\cline { 1 - 5 } Post-test & 30 & 30.20 & 4.56 & & & 01 level \\
\hline
\end{tabular}

It is revealed from the table-1, the mean scores of pre-test and post-test is found 25.36 and 30.20 respectively with standard deviation 4.49 and 4.56 . The t-ratio between the two tests is found 4.17, which interprets the significant difference between the two tests. That means there is a significant difference between pre-test and post-test scores in achievement test among secondary school students.
Further, the mean score of post-tests is higher than the pretest score. It indicates that the intervention program i.e. teaching through ICT has significant effect.

Hypothesis-2: There exist a significant difference between the post-test score of male and female secondary students in the achievement test.

Table 2: Significance of difference between the post-test score of male and female secondary students in the achievement test

\begin{tabular}{|c|c|c|c|c|c|c|}
\hline Group & N (No. of samples) & Mean & S. D. & S. Ed. & t-ratio & Level of significance \\
\cline { 1 - 4 } Male & 15 & 29.86 & 3.17 & \multirow{2}{*}{1.68} & \multirow{2}{*}{0.39} & $\begin{array}{c}\text { No significant difference } \\
\text { at any level }\end{array}$ \\
\hline Female & 15 & 30.53 & 5.35 & & \\
\hline
\end{tabular}

It is revealed from the table-2, the mean scores of post-test score of male and female group is found 29.86 and 30.53 respectively with standard deviation 3.17 and 5.35 . The tration between the two groups is found 0.39 , which interprets there is no significant difference between the two group. Further, the mean score of post-tests of female students is higher than the post-test score of male groups. It indicates that the intervention program i.e. teaching through
ICT has no significant effect on the gender. Thus, the hypothesis that there exists a significant difference between the post test score of male and female secondary students on physical science achievement test is discarded.

Hypothesis-3: There exists a significant difference between the post- test score of rural and urban secondary students in the achievement test.

Table 3: Significance of difference between the post-test score of rural and urban secondary students in the achievement test

\begin{tabular}{|c|c|c|c|c|c|c|}
\hline Group & N (No. of samples) & Mean & S. D. & S. Ed. & t-ratio & Level of significance \\
\cline { 1 - 3 } Urban & 15 & 31.4 & 4.89 & 1.63 & \multirow{2}{*}{1.47} & $\begin{array}{c}\text { No significant difference } \\
\text { at any level }\end{array}$ \\
\hline Rural & 15 & 29 & 4.01 & & \\
\hline
\end{tabular}


It is revealed from the table-3, the mean post test scores of urban and rural groups is found 31.4 and 29 respectively with standard deviation 4.89 and 4.01 respectively. The tration between the two groups is found 1.47, which interprets there is no significant difference between the two groups. Further, the mean score of post-tests of rural students is higher than the post-test score of urban students. It indicates that the intervention program i.e. teaching through ICT has no significant effect on the locality of students. Thus, the hypothesis that there exists a significant difference between the post test score of rural and urban secondary students on physical science achievement test is discarded.

\section{Recommendations}

The study is conducted by taking few samples; it may also conduct by taking large sample. Here in this case the study is conducted by taking one secondary school but for the convenience for better generalization the study may be undertaken by taking other secondary schools. Furthermore, it may also conduct on primary, upper primary and higher education institutions and also may undertake by taking teachers as the samples in order to know their efficiency in teaching process and digital literacy.

\section{Discussion and Conclusion}

Now a day's use of ICT in the classroom is very essential for effective teaching learning process. Teachers and students both are getting easy for their work in limited time. The finding of the present study revealed that there exists significant difference between the pre-test and post-test scores on the achievement test among secondary school students. Further the study also revealed that there is no significant difference in the post test scores on the achievement test irrespective of gender and locality groups.

\section{References}

1. Avinash A, Shailja S. The impact of ICT on achievement of students in chemistry at secondary level of CBSE and up board in India. International Journal of Science and Research 2013;2(8):126-129.

2. Carrillo P, Onofa M, Ponce J. Information technology and students achievement: Evidence from a randomized experiment in Ecuador. Inter-American Development Bank: Department of Research and Chief Economist. IDB Working Paper Series No. IDB-WP-223 2010.

3. Eguavoen EO. ICT Utilization As Correlates Of Academic Performance Among Students With Visual Impairment In Lagos State, Nigeria, European Scientific Journal 2016;12(13):622-629.

4. Nisar MF, Munir EU, Shad SA. Usage and Impact of ICT in Education Sector; A Study of Pakistan, Australian Journal of Basic and Applied Sciences 2011;5(12):578-583.

5. Safdar A, Yousuf MI, Parveen Q, Behlol MG. Effectiveness of Information and Communication Technology (ICT) in teaching mathematics at secondary level. International Journal of Academic Research 2011;3(5):67-72.

6. Sharma P. A Study of the Impact of Ict Tools on Achievement of Students in Learning Educational Technology, International Journal of Research 2014;1(6):76-92.
7. Ziden AA, Ismail I, Spian R, Kumutha K. The effects of ICT use in teaching and learning on students' achievement in science subject in a primary school in Malaysia. Malaysia Journal of Distance Education 2011;13(2):19-32. 